\title{
"Franchise business sustainability model: Role of conflict risk management in Indonesian franchise businesses"
}

\begin{tabular}{|c|c|}
\hline AUTHORS & $\begin{array}{l}\text { Dorojatun Prihandono (i) } \\
\mathbb{R} \\
\text { Andhi Wijayanto (i) } \\
\mathbb{R} \\
\text { Dwi Cahyaningdyah (D) }\end{array}$ \\
\hline ARTICLE INFO & $\begin{array}{l}\text { Dorojatun Prihandono, Andhi Wijayanto and Dwi Cahyaningdyah (2021). } \\
\text { Franchise business sustainability model: Role of conflict risk management in } \\
\text { Indonesian franchise businesses. Problems and Perspectives in Management, } \\
\text { 19(3), 383-395. doi:10.21511/ppm.19(3).2021.31 }\end{array}$ \\
\hline DOI & http://dx.doi.org/10.21511/ppm.19(3).2021.31 \\
\hline RELEASED ON & Tuesday, 21 September 2021 \\
\hline RECEIVED ON & Friday, 16 July 2021 \\
\hline ACCEPTED ON & Wednesday, 08 September 2021 \\
\hline LICENSE & $\begin{array}{l}(c) \text { EY } \\
\text { This work is licensed under a Creative Commons Attribution } 4.0 \text { International } \\
\text { License }\end{array}$ \\
\hline JOURNAL & "Problems and Perspectives in Management" \\
\hline ISSN PRINT & $1727-7051$ \\
\hline ISSN ONLINE & $1810-5467$ \\
\hline PUBLISHER & LLC "Consulting Publishing Company "Business Perspectives" \\
\hline FOUNDER & LLC "Consulting Publishing Company "Business Perspectives" \\
\hline
\end{tabular}

NUMBER OF REFERENCES

50
NUMBER OF FIGURES

1
NUMBER OF TABLES

7

(C) The author(s) 2021. This publication is an open access article. 


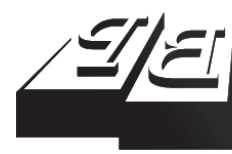

BUSINESS PERSPECTIVES

(O)

LLC "CPC "Business Perspectives" Hryhorii Skovoroda lane, 10 Sumy, 40022, Ukraine www.businessperspectives.org
Received on: $16^{\text {th }}$ of July, 2021 Accepted on: $8^{\text {th }}$ of September, 2021 Published on: $21^{\text {st }}$ of September, 2021

(C) Dorojatun Prihandono, Andhi Wijayanto, Dwi Cahyaningdyah, 2021

Dorojatun Prihandono, Ph.D., Lecturer, Faculty of Economics, Department of Management, Universitas Negeri Semarang, Indonesia. (Corresponding author)

Andhi Wijayanto, M.M., Lecturer Faculty of Economics, Department of Management, Universitas Negeri Semarang, Indonesia.

Dwi Cahyaningdyah, Dr., Lecturer Faculty of Economics, Department of Management, Universitas Negeri Semarang, Indonesia.
This is an Open Access article distributed under the terms of the Creative Commons Attribution 4.0 International license, which permits unrestricted re-use, distribution, and reproduction in any medium, provided the original work is properly cited.

Conflict of interest statement: Author(s) reported no conflict of interest
Dorojatun Prihandono (Indonesia), Andhi Wijayanto (Indonesia),

Dwi Cahyaningdyah (Indonesia)

\section{FRANCHISE BUSINESS}

\section{SUSTAINABILITY MODEL: ROLE OF CONFLICT RISK MANAGEMENT IN INDONESIAN FRANCHISE BUSINESSES}

\section{Abstract}

Franchising is one of the most trustworthy strategic alliance formations to start or expand businesses. Like many other business formations, franchise businesses need sustainable and long-term running; these objectives can be reached by a proper relationship between partners - the franchisor and the franchisee - in the alliances. Both partners' perspectives are valuable inputs to provide insight into understanding the sustainability of Indonesian franchise businesses. Furthermore, in any type of strategic alliances conflict is a risk that needs to be managed properly. This study aims to examine the relationships of determinants that influence franchise business sustainability. The determinants are risk management, trust, satisfaction, and sustainability. The study applies confirmatory factor analysis using structural equation modeling (SEM) AMOS software. Respondents in this study are franchisors and franchisees in the Indonesian retail and food and beverages (F\&B) sectors, the study accommodates 204 respondents. Based on the analysis the study reveals that there is a positive relationship between risk management and satisfaction. Risk management also has a positive relationship with survivability; trust and satisfaction also have a positive relationship. Meanwhile, there is no relationship between satisfaction and survivability and the last relationship is between trust and survivability that has no positive relationship between the determinants. This study provides clearer insight to understand the relationships between determinants that influence franchise business survivability in Indonesia, especially based on both parties' perspectives.

\section{Keywords} survivability, risk management, satisfaction, conflict, franchisor, franchisee

\section{JEL Classification $\quad$ M20, M21, M31}

\section{INTRODUCTION}

Proper relationship in franchise business formation builds proper cooperation between partners: the franchisor and the franchisee. Both parties are expected to maintain their relationship to establish survivability and sustainable businesses. Along the business progresses, the franchise businesses might and surely will encounter any disputes that can lead to failures. The conflict between partners generally related to moral hazard and path dependency (Gant \& Buchan, 2019), lack of entrepreneurial orientation (Botha \& Prawlall, 2018), the next is loan issue (Alon et al., 2015), and trust (Dada et al., 2012; Sanny et al., 2017). Previous studies in the franchising area were in the western context, so there is a need to develop a study to examine determinants that influence franchise business survivability in Indonesia. Mostly, Indonesian franchisee businesses are in the food and beverages sectors or retail sectors. Indonesia's franchise survivability has not been profoundly examined, therefore requires an analysis regarding franchise business survivability issue. The ability to survive is related to business problem solving and cooperation trust; therefore, the ability 
to maintain a proper relationship between franchisee and franchisor is pertinent. Previous studies have not examined the influence of trust on survivability; therefore, this study aims to examine this effect especially in franchise businesses. Business risk mitigation is also needed to reduce failure in franchise business relationships. Franchisee risk mitigation should establish information seeking to both parties: the franchisee and the franchisor. The risk in doing business using the franchise formation can be in the form of conflict between franchisor and franchisee, the conflict will cause instability in the relationships, and it can lead to business termination (Grace \& Weaven, 2011).

\section{LITERATURE REVIEW AND HYPOTHESES DEVELOPMENT}

Franchising is an agreement in a business strategic alliance in which the franchisor provides a license to an individual or other company, and the franchisee runs a business as determined in a certain period, where the franchisor gives the right and business license and in return, the franchisor will earn royalties and other types of payments (Lee et al., 2015). In the sense of the modern business world, the franchise agreement covers several important concepts: market-testing business packages, self-financing of franchises, and corporate franchises or multi-unit franchisees (Hodge et al., 2013). Moreover, franchising is a form of relations exchange in which the parties in the franchise agreement are commercially dependent on each other and create a continuing 'tense and ease action' between them (Grace et al., 2016).

All types of business formations bear risk, and risk is a decisive factor in business, especially in a strategic business alliance such as franchising where parties are involved in managing the businesses. Managing the risk of business is a challenging task for managers. One of the potential risks that may arise in a business alliance is the bankruptcy of the alliance; one of the main triggers is due to conflicts between parties in the alliance (Das \& Kumar, 2010). Cultural barriers and mismatches of 'chemistry' between persons in a strategic alliance might cause business failure ( $\mathrm{Wu}, 2015)$.

This study aims to examine the determinants' relationships based on the two parties' perspectives who are bound in a franchise agreement and to develop a risk management scheme in non-financial businesses to increase the survivability of Indonesia's franchise business.
Risk between parties in strategic alliances such as franchise business arrangements should be managed properly. Business managers in a franchise carry out the process of identifying risks and various challenges in business, including how to manage the relationship between partners, which has become a routine activity for them. In a paradigm of proper business-to-business (B2B) relationships, companies can create and maintain their competitive advantage by acquiring several actions to ensure that the alliances are still intact cohesively. In practice, there is a possibility that one of the parties has a more dominant role (Blois, 2009). This more dominant role can be in the form of a greater influence so that the other party acts according to what he wants; therefore, the term 'equal' rights and obligations in $\mathrm{B} 2 \mathrm{~B}$ relationships are important to ensure good relationships. In a franchise agreement, the perception of equity is based on the franchisor and franchisee (Grace et al., 2016). The issue of equity is still a debate (Blois, 2009); therefore, normative expectations of equity are related to the correlation between input and output which is considered "fair" in a partnership (Blois, 2009). Proper relationships between partners will lead to the formation of a successful business, where delivery of product or service is improved and maintained for the partners' benefit (Wang \& Lee, 2009). Franchise agreements have characteristics indicated by a series of relational exchanges, the success of which depends on how to manage and maintain costs and profits from partners (Harmon \& Griffiths, 2008). Maintaining a good relationship between partners is very essential so that the advantages expected from this franchise cooperation will not be realized if there is no goodwill from the partners (Antia et al., 2013). As with other business alliances, the selection of potential business partners is seen as something hazardous, furthermore, once the business is formed, the risk exists in the form of how to manage the collaboration or cooperation. The types of risks that arise 
in the franchise business are generally related to conflict occurrence (Doherty et al., 2014).

An effort to resolve conflicts between franchisors and franchisees is to understand the conflict's initiates (Weaven et al., 2012). This type of conflict arises when a lack of cooperation between partners can lead to opportunistic actions between them, in which these actions can be manifested in several ways, such as incompatibility with the franchise system, misunderstanding, suitability of outlet locations, problems with marketing areas, profitability, communication problems and franchise fees (Grace et al., 2016). The risk of this conflict can provoke proper relations between partners, resulting in the emergence of misunderstandings. If the misunderstanding will result in conflict between partners and can be fatal, the parties to the franchise agreement need to have the means to maintain good relational relationships and minimize the emergence of opportunistic behavior (Ishida \& Brown, 2013). To minimize the potential for conflict, partners need to be aware of the possibility of conflict (Weaven et al., 2012). By minimizing potential conflict, the level of relational relationships between partners will reach a level of satisfaction for both of them, and this ideal condition will create a productive relationship from a business perspective (Frazer et al., 2012; Wright \& Grace, 2011). Satisfaction with the relationship between the franchisor and the franchisee is thought to influence survivability, therefore further testing is needed.

A productive business relationship in a strategic alliance such as a franchise is important, given the market competition's very intensive level (Wright \& Grace, 2011). The level of pressure in the relationship between businesses needs to be maintained, meaning that if the pressure increases to lead to an inharmonious relationship, it needs to be resolved in an appropriate way to reduce the level of tension between the parties doing business (Altinay et al., 2014; Davies et al., 2011). The management of this relationship is crucial, considering that business in strategic alliances is seen as vulnerable to conflicts between partners in it. Dada and Watson (2013) also emphasized that in a franchise agreement, personal relationships between franchisors and franchisees are very important to be maintained at a good level to ensure the sus- tainability of the business. The improvement of relationships has an important role in determining the success of alliance businesses such as franchising, and if there is no agreement between the two parties in the franchise, it can have negative consequences for this collaborative relational relationship (Doherty, 2009; Altinay \& Brookes, 2012). Fostering proper relationships between parties in a franchise agreement is quite challenging, considering that each person has their characteristics, which is why increasing relational relationships play an important role in maintaining good relational relationships between franchisors and franchisees (Altinay et al., 2014).

The relationship between partners is dynamic, and throughout the business activity there will be up and down relationships; in this context, trust has become a factor that can provide each party with a minimum amount of doubtfulness that can bring the solid relationship into a vulnerable state (Atinay \& Brookes, 2012). Furthermore, in alliances such as franchising, actions done by each party would have an impact on their trust, on several occasions, the actions can be a little bit too far out of the course. This kind of thing can reduce the level of trust and in the forthcoming, it can have a negative impact on the business performance. If the business performance deteriorates it will affect the business relationship between parties, trust between them will decrease as well (Croonen, 2010). According to a previous study by Davies et al. (2011), if there is a strong trust between partners they will obey their agreement, each partner will perform the business as it should be based on their rights and obligations, and moreover, business performance will increase and the business will survive in the future. Croonen (2010) also emphasized that trust is a significant foundation of competitive advantage and Frazer et al. (2012) added that trust also plays a huge role in decreasing the level of conflict and it can lead to business survivability.

This study aims to examine the determinants' relationships based on the two parties' perspectives who are bound in a franchise agreement. Second, this study also aims to develop a risk management scheme in non-financial businesses to increase the survivability of Indonesia's franchise business. 


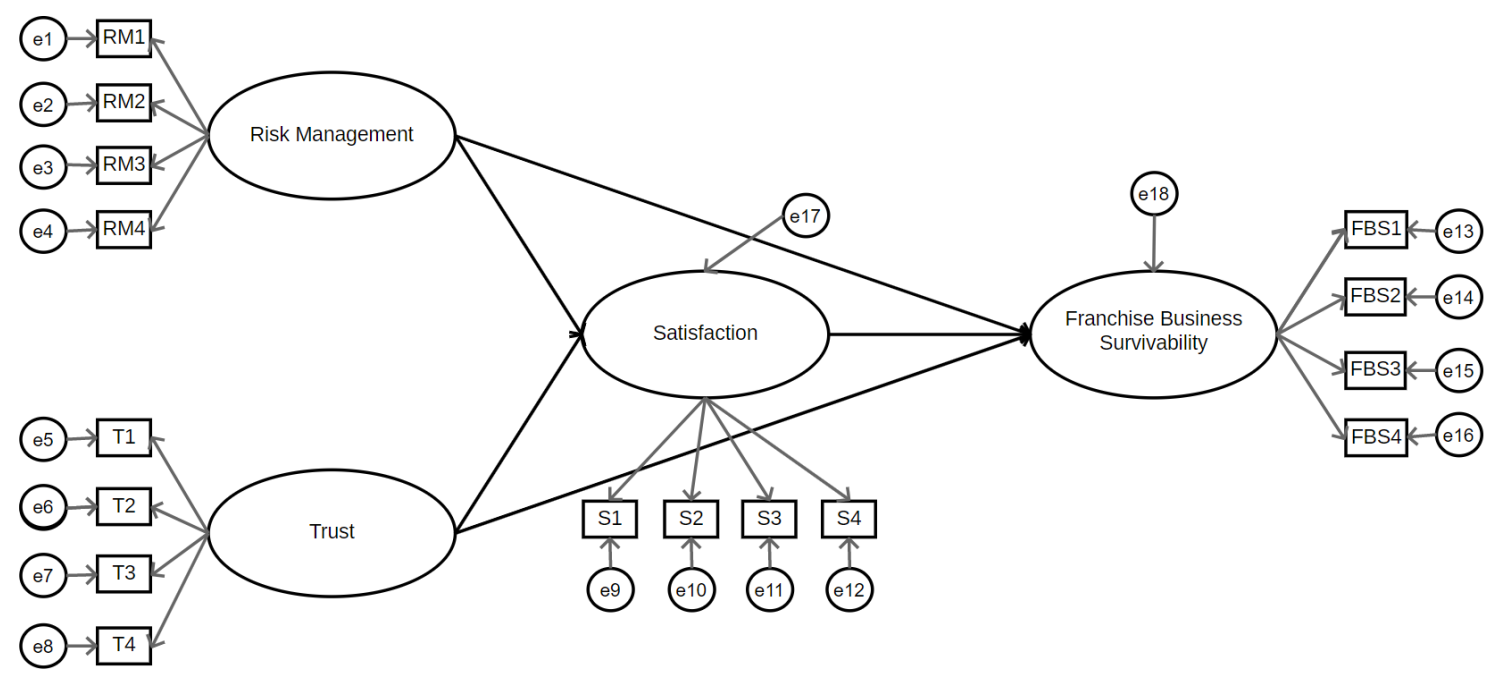

Figure 1. Research model

Based on the abovementioned, this study develops hypotheses as follow:

$\begin{array}{ll}H_{1}: & \text { Risk management has a positive influence on } \\ & \text { franchise business survivability. }\end{array}$

$H_{2}: \quad$ Risk management has a positive impact on parties' level of satisfaction.

$H_{3}:$ If each partner is satisfied with the relationship, the level of business survivability increases.

$\mathrm{H}_{4}$ : $\quad$ Trust increases the level of parties' satisfaction in the franchise business formation.

$H_{5}: \quad$ The level of trust between parties increases the level of franchise business survivability.

Figure 1 shows the model of this study.

\section{METHODS}

This study applies a quantitative method, using confirmatory analysis (Brown, 2003) with SEM AMOS as the software analysis. The population of this study is managers and business owners of franchise businesses in the retail and F\&B sectors in Indonesia. There are 204 franchisors and franchisees as a population, based on the formula, when the degree of significance is 0.05 , the sample needed is $204 / 1+204(0.05)^{2}=204 / 1.525=135$.
Therefore, the minimum needed sample is 135 .

$$
n=\frac{N}{1+N \cdot(e)^{2}} .
$$

Based on the sampling method, this study acquires 138 samples. This study uses a non-probability sampling technique. This sampling method is based on selecting respondents based on certain criteria there are F\&B owner or manager of a franchise business, at least one year of experience managing a franchise business, and an entrepreneur who legally has a franchise business. The indicators for the construct determinant of conflict risk management are pre-investment screening, due diligence, opportunistic behavior, and market demand (Anderson \& Weitz, 1992; Blut et al., 2011; Grace et al., 2013). Based on Rodrigues and Wilson (2002), and Johnston et al. (2004), indicators for trust are 'goodwill trust', 'competence trust', 'cognition-based trust', and 'affect-based trust'. Satisfaction has several indicators, there are 'resource access', 'communication openness', 'perceived conflict', and 'support' (Palmatier, 2006; Davies et al., 2011). Survivability has several indicators, there are 'franchise expectations core competency fit or misfit', 'franchise expectations and core competency fit or misfit', 'partners' complaints and legal actions', 'strategic achievement', and 'business formula testing' (Stanworth et al., 2001; Holmberg \& Morgan, 2004; Davies et al., 2011; Winsor et al., 2012). Appendix A shows the table of the indicators, statements and references 
for each construct determinants, while the appendix $B$ shows the questionnaire and scale of this research.

\section{RESULTS}

\subsection{Validity test results}

The first step is to test the validity to find out that the data is valid, and then it can be tested using the reliability test. The validity test uses Pearson correlation to obtain the value of the data that has been obtained. The results of the Pearson correlation test are shown in Table 1.

Table 1. Validity test results

\begin{tabular}{c|c}
\hline Parameter & Pearson correlation value \\
\hline T1 & 0.736 \\
\hline T2 & 0.723 \\
\hline T3 & 0.782 \\
\hline T4 & 0.696 \\
\hline RM1 & 0.894 \\
\hline RM2 & 0.917 \\
\hline RM3 & 0.857 \\
\hline RM4 & 0.869 \\
\hline Sa1 & 0.678 \\
\hline Sa2 & 0.746 \\
\hline Sa3 & 0.754 \\
\hline Sa4 & 0.702 \\
\hline Su1 & 0.862 \\
\hline Su2 & 0.841 \\
\hline Su3 & 0.771 \\
\hline Su4 & 0.714 \\
\hline
\end{tabular}

Note: T means Trust; RM means Risk Management; Sa means Satisfaction; Su means Survivability.
Table 1 shows that the Pearson correlation value has met the research rules at the $5 \%$ significance level. This indicates that the data obtained during the study shows a valid value. The reliability test is shown in Table 2.

\subsection{Reliability test results}

All variables have met the reliability criteria because Cronbach's alpha value is $>0.6$ (Brown, 2003).

Based on hypotheses testing, three hypotheses are supported, and two hypotheses are not supported. There is a positive and significant effect of risk management on satisfaction with a CR value of $5.288(\mathrm{sig}=0.000)$, it is indicated risk management implementation builds satisfaction. Trust has a positive and significant effect on satisfaction (CR $=2.535$, sig $=0.011<0.05$, when trust establishment encourage satisfaction for both franchisee and franchisor. Risk management has a positive and significant effect on survivability $(\mathrm{CR}=2.482$, sig $=0.013<0.05)$. Trust has no effect on survivability $(\mathrm{CR}=0.550$, sig $=0.583>0.05)$ and satisfaction does not impact survivability $(\mathrm{CR}=1.403$, sig $=0.161>0.05$ )

This study proves trust positively affects the satisfaction of the relationship between the franchisor and the franchisee. This study strengthens the previous study, which shows a positive and significant relationship between trust and cooperation satisfaction, a collaboration that is built needs to be based on trust so that there are no spaces that lead to dissatisfaction, and suspicion can be re-

Table 2. Reliability test results

\begin{tabular}{|c|c|}
\hline Reliability & Cronbach's alpha \\
\hline Trust & 0.714 \\
\hline Risk management & 0.906 \\
\hline Satisfaction & 0.682 \\
\hline Survivability & 0.81 \\
\hline
\end{tabular}

Table 3. Research result

\begin{tabular}{l|c|c|c|c|c}
\hline \multicolumn{1}{c}{ Variable relationship } & Estimate & S. E & CR & P & Results \\
\hline Risk management $\rightarrow$ Satisfaction & .511 & .097 & 5.288 & $* * *$ & Supported \\
\hline Trust $\rightarrow$ Satisfaction & .356 & .140 & 2.535 & 0.011 & Supported \\
\hdashline Risk management $\rightarrow$ Survivability & .568 & .229 & 2.482 & 0.013 \\
\hline Trust $\rightarrow$ Survivability & -.129 & .234 & -.550 & 0.583 & Supported supported \\
\hdashline Satisfaction $\rightarrow$ Survivability & .541 & .386 & 1.403 & 0.161 & Not supported \\
\hline
\end{tabular}


duced and eliminated (Dickey et al., 2007; Grace et al., 2016). A contract must be kept, an agreement that both parties have agreed should be implemented so that no interpretation can lead to a conflict. This can reduce the sense of satisfaction of both parties for the emergence of a disharmony that arises. In addition, business partners, especially franchisors, need to be relied on to improve relational relationships in franchise relationships. This study proves that trust does not directly affect survivability but tends to result in the satisfaction generated from the cooperation between the franchisor and the franchisee. This study proves that satisfaction is not always the main basis for determining business survivability. This study has shown that risk management can be positively and significantly related to the satisfaction of the cooperation relationship between franchisees and franchisors. This study has proven that the ability to mitigate risk well has a positive effect on satisfaction.

\section{DISCUSSION}

The relationship between the franchisor and the franchisee is a business relationship that exists to cooperate in a franchise business. This relationship has two possibilities: mutual support between two parties or opportunistic behavior that can harm either party (Watson \& Johnson, 2010). A contract is a tool in guiding the franchisor and the franchisee relationship. Even so, it does not rule out the possibility of an improper relationship. Therefore, trust in establishing business relationships is essential (Davies et al., 2011). Relationships based on opportunistic behavior between the two parties can reduce the sense of trust and stretch the relationship in the future. For example, when a franchisor tries to enter the business area, the franchisee's satisfaction will decrease, resulting in suspicion from the franchisee because opportunistic actions can injure a relationship and affect future cooperation. Suspicion can lead to dissatisfaction on the part of the franchisee.

Relational contract theory is a theory that explains that some contracts or agreements cannot be fully carried out by either the maker or the other party so that suspicions can arise from other parties (Baker et al., 2002). This study strengthens relational contract theory in which an agreement that has been agreed upon by both parties, in this case, is between a franchisor with franchisees and is carried out properly, it has implications for increasing the sense of trust that arises from both parties and a sense of satisfaction over the existing cooperation so far (Grace et al., 2016; Wright \& Grace, 2011). Collaboration in any business relationship needs further discussion to discover detail in the contracts that have been established so that the trust that arises can increase with the points of agreement carried out by both parties, a contract needs an explanation that can allow multiple interpretations to emerge. This can have implications for increasing the satisfaction of cooperation that exists between the franchisor and the franchisee.

Perception can play an important role in increasing trust and satisfaction so that both parties can provide mutual trust and ensure that the contract that has been agreed upon can run smoothly. Franchisees who feel that the franchisor gives goodwill will provide a sense of trust and increase the cooperation established so far (Weaven et al., 2012). Franchisees require ongoing guidance and training to improve the performance or performance of a franchise. The existence of good intentions from the franchisor will increase satisfaction with the currently built cooperation. The broader implication is cooperation in the future. Besides, trust is needed in businesses, therefore franchise businesses can operate smoothly without any disruption in a collaboration.

Franchisors need to provide the support that is considered important to franchisees so that the performance that appears is getting better and increasing continuously. Trust is essential for growing a business and can be beneficial for both parties. Cooperation based on trust can provide a satisfying collaborative relationship that can have positive implications in running a business (Altinay et al., 2014). If a business is not satisfied, then for the franchisor and franchisee the relationship does not work harmoniously. However, there is a continuous effort without the satisfaction of the cooperation agreement. In principle, a harmonious relationship is a key to exchanging knowledge that a party has (Nyadzayo et al., 2015). Franchisors who provide knowledge about the 
management of a business can be put to good use by franchisees, so that satisfaction arises and can encourage business survivability.

Satisfaction reflects the relationship that exists between both parties. Dissatisfaction with the relationship indicates a conflict that can cause a franchise business to continue in the future but ruin the relationship. The franchisor's role is very important in providing knowledge and business development to make the franchisee able to perform better business performance in the future consistently and continuously, along with the strengthening of the franchisor's reinforcement. Satisfaction is an indication that reflects a harmonious relationship between franchisees and franchisors, so the implication is business survivability. When a business can run continuously in the future, this is due to the development of materials and business strategies needed to improve performance. A collaboration owned by the franchisor and franchisee can encourage business survivability formed on the strategic achievement of a business in the franchise concept that cannot be separated from the existence of a strategy to encourage the achievement of a goal (Stanworth et al., 2001). One of the business objectives is to encourage an increase in expansion and an increasing number of market shares to increase sales; the expected result is an increase in the number of sales and is directly proportional to the amount of income that is owned. A business with a belief can build a strategic achievement so that both the franchisor and the franchise can implement the planned strategy in the implementation stage. This achievement is inseparable from the trust and satisfaction during the collaboration between parties along with the cooperation that reflects the balanced relationship that can achieve a strategy by exchanging knowledge through knowledge sharing.

The cooperation relationship between the franchisor and franchisee is an expectation built based on trust to achieve predetermined goals, namely the wider market share that is owned and the income that continues to increase (White, 2010). A business is conjoined with the potential risks that might arise from cooperative relationships with other parties so that a franchisee who wants to have a franchise business and wants to work with other parties, namely the franchisor, needs to mit- igate a relationship. The risks that can arise as a consequence of a business can be mitigated by earlier screening in the contract agreement and franchisees can identify in advance through other parties in gathering information about the franchisor's reputation who has a franchise business (Aliouche \& Schlentrich, 2011). A franchisee who collects information in advance regarding a franchisor license can minimize risk. Business legality and information are beneficial for franchisee consideration to create a decision; therefore, it is being the first screening to establish cooperation (Mainardes et al., 2019). The agreement contract is a vehicle for franchisees to recognize in advance through other parties in gathering information about the franchisor's reputation who has a franchise business. This study has shown that risk management can have a positive and significant relationship to the satisfaction of the cooperative relationship between the franchisee and the franchisor.

This study has proven that the ability to mitigate risk well has a positive effect on satisfaction, meaning that a franchisee who first collects information about the franchisor who has a franchise license can minimize a risk that can arise so that a franchisor is not easy to believe. The information collected can strengthen the initial information that can increase awareness in managing business risks. A business partner needs to know its reputation before signing a contract (Aliouche et al., 2012). Therefore, if a content fan already knows in advance about the franchisor's reputation, this can encourage satisfaction because the information obtained is complete enough so that the possibility of default is getting smaller. Therefore, the satisfaction possessed by the franchisee in a business cooperation relationship increases when carrying out an information search, franchisee needs to research market information so that the information obtained is not only about the reputation of the franchisor; as a result, the franchisee can predict demand for goods produced or sold when the agreement or contract is signed.

A larger market share is an attraction that encourages franchises to make a contract with the franchisor; the wider the market share they have, the greater the business opportunities will be (Doherty, 2009). Cooperation implementation encourages better performance; hence, it reduces 
opportunistic behavior from franchisors or franchisees. Risk management is a suitable strategy when one party is not able to conduct according to the signed contract (Liu, 2016). This study indicates that risk management regarding opportunistic behavior can encourage cooperation carried out by both parties.

This study has proven that risk management does not directly affect business survivability but the satisfaction of the cooperation that exists between the franchisor and the franchise fully mediates the relationship between risk management and business survivability. This study proves that satisfaction with cooperation reflects the harmonious relationship between franchisors and franchisees, but it does not always have a positive effect on business continuity. Franchises can survive from time to time with a harmonious relationship between franchisors and franchisees. A franchisee needs to mitigate the relationship between the franchisee and the franchisor to avoid opportunistic behavior. Risk management has a direct effect on business survivability. Cooperation satisfaction that exists between the franchisor and the franchisee does not mediate the relationship between risk management and business survivability (Madanoglu et al., 2019)

Risk management business formation can strengthen franchisees against losses caused by testing new business formulations, testing busi- ness formulations does not necessarily show success in several circumstances (Perrigot et al., 2014). Risk management is also a significant factor to reduce a loss from incomplete information. Franchisees should look for a franchisor with a good reputation. When a franchisor has a good reputation, this can be related to the business survivability. When a franchisee cannot maintain the current business capital or the number of requests is decreasing, this can encourage a business to close faster than the time predicted. A franchisee needs to obtain comprehensive information to obtain the capabilities and capacities of the franchisor in assisting the transition of the business survivability (Raha \& Hajdini, 2020). Adaptability and an ideal business model are important components in determining the sustainability of a business in the future. Risk management attempts to collect complete information regarding business reputation with a significant relationship with the business survivability of one party (Fraser \& Simkins, 2016). The results of this study are consistent with the previous study, namely strengthening the relationship between risk management on cooperation satisfaction and business survivability. A business cannot stand by itself, so there is a need for support from other parties-the franchisors or the franchises to rectify risk management and relationship to sustain the business in the long term.

\section{CONCLUSION}

This study has addressed the problems in examining the relationship between determinants of franchise business survivability in Indonesia, especially in the retail and F\&B sectors. There is some evidence based on both parties' perspectives that acquiring risk management scheme in assessing the risk of conflict will have a positive influence on franchise business survivability. The next is that the study also shed a light on how other determinants influence this process. Risk management also has a positive contribution in obtaining the partners' satisfaction in enduring their relationships. This shows that if each partner or party is aware of conflicts that may occur, they will comply with the contract and provide the alliances with a feeling of contentment in each party. Trust also plays a positive role in providing partners with a level of satisfaction, as this will affect how they will work together in the alliances to reach the goals of the businesses. On the other hand, two hypotheses are not supported; there is the relationship between satisfaction and survivability and the relationship between trust and survivability. This phenomenon provides franchise business formation with evidence that led to providing more and continuous risk management schemes in the strategic alliances such as franchising. Risk management, especially in non-financial aspects, can be a strategic and pertinent determinant to ensure the franchise formation reaches its goals and objectives as a continuous business. This study also demonstrates that trust and satisfaction perhaps are not sufficient in ensuring the businesses will survive in long term pe- 
riod. It needs risk management schemes and approaches to provide partners with insight in identifying risks to avoid conflict that can lead to businesses termination.

This study can be a valuable source for franchise businesspeople to build a solid relationship between franchisors and franchisees. Franchise businesses are encouraged to adopt a risk management scheme to enhance their franchise business survivability. This paper provides a guideline to strengthen their business strategy and achieve continuous business performance. This study also examined antecedents of business survivability; in the future, another study needs to offer analysis using other determinants so that it can provide the franchising area with more broad variations of determinants that might have an impact on improving the franchise business survivability.

\section{AUTHOR CONTRIBUTIONS}

Conceptualization: Dorojatun Prihandono.

Data curation: Dorojatun Prihandono.

Formal analysis: Dorojatun Prihandono.

Investigation: Dorojatun Prihandono.

Methodology: Dorojatun Prihandono.

Project administration: Dorojatun Prihandono.

Supervision: Dorojatun Prihandono, Andhi Wijayanto, Dwi Cahyaningdyah.

Validation: Dorojatun Prihandono, Andhi Wijayanto, Dwi Cahyaningdyah.

Visualization: Dorojatun Prihandono, Andhi Wijayanto.

Writing - original draft: Dorojatun Prihandono.

Writing - review \& editing: Dorojatun Prihandono, Andhi Wijayanto, Dwi Cahyaningdyah.

\section{REFERENCES}

1. Aliouche, E. H., Kaen, F., \& Schlentrich, U. (2012). The market performance of franchise stock portfolios. International Journal of Contemporary Hospitality Management, 24(5), 791-809. https://doi. org/10.1108/09596111211237309

2. Aliouche, E. H., \& Schlentrich, U. A. (2011). Towards a Strategic Model of Global Franchise Expansion. Journal of Retailing, 87(3), 345-365. https://doi. org/10.1016/j.jretai.2011.01.004

3. Alon, I., Boulanger, M., Misati, E., \& Madanoglu, M. (2015). Are the parents to blame? Predicting franchisee failure. Competitiveness Review, 25(2), 205-217. https://doi. org/10.1108/CR-10-2014-0034

4. Altinay, L., \& Brookes, M. (2012). Factors influencing relationship development in franchise partnerships. Journal of Services Marketing, 26(4). https://doi. org/10.1108/08876041211237578
5. Altinay, L., Brookes, M., Madanoglu, M., \& Aktas, G. (2014). Franchisees' trust in and satisfaction with franchise partnerships. Journal of Business Research, 67(5), 722728. https://doi.org/10.1016/j. jbusres.2013.11.034

6. Anderson, E., \& Weitz, B. (1992). The Use of Pledges to Build and Sustain Commitment in Distribution Channels. Journal of Marketing Research, 29(1). https://doi. org/10.1177/002224379202900103

7. Antia, K. D., Zheng, X., \& Frazier, G. L. (2013). Conflict management and outcomes in franchise relationships: The Role of Regulation. Journal of Marketing Research, 50(5), 577589. https://doi.org/10.1509/ jmr.11.0144

8. Baker, G., Gibbons, R., \& Murphy, K. J. (2002). Relational contracts and the theory of the firm. Quarterly Journal of Economics,
117(1), 39-84. https://doi. org/10.1162/003355302753399445

9. Blois, K. (2009). Equity within business to business relationships. Journal of Marketing Management, 25(5-6), 451-459. https://doi. org/10.1362/026725709X461795

10. Blut, M., Backhaus, C., Heussler, T., Woisetschläger, D. M., Evanschitzky, H., \& Ahlert, D. (2011). What to Expect After the Honeymoon: Testing a Lifecycle Theory of Franchise Relationships. Journal of Retailing, 87(3). https://doi.org/10.1016/j. jretai.2010.06.003

11. Botha, M., \& Prawlall, T. (2018). Investigating the effect of location, specifically shopping centres, on franchisees' entrepreneurial orientation: A cluster analysis. South African Journal of Business Management, 48(3). https://doi. org/10.4102/sajbm.v48i3.32

12. Brown, T. A. (2003). Confirmatory factor analysis of the Penn 
State Worry Questionnaire: Multiple factors or method effects? Behaviour research and therapy, 41(12), 1411-1426. https://doi.org/10.1016/S00057967(03)00059-7

13. Croonen, E. (2010). Trust and Fairness During Strategic Change Processes in Franchise Systems. Journal of Business Ethics, 95, 191-209. https://doi.org/10.1007/ s10551-009-0354-Z

14. Dada, O., \& Watson, A. (2013) The effect of entrepreneurial orientation on the franchise relationship. International Small Business Journal, 31(8), 955-977. https://doi. org/10.1177/0266242612446035

15. Dada, O., Watson, A., \& Kirby, D. A. (2012). Toward a model of franchisee entrepreneurship. International Small Business Journal, 30(5), 559-583. https://doi. org/10.1177/0266242610376078

16. Das, T. K., \& Kumar, R. (2010) Interpartner sensemaking in strategic alliances: Managing cultural differences and internal tensions. Management Decision, 48(1), 17-36. https://doi. org/10.1108/00251741011014436

17. Davies, M. A. P., Lassar, W., Manolis, C., Prince, M., \& Winsor, R. D. (2011). A model of trust and compliance in franchise relationships. Journal of Business Venturing, 26(3), 321-340. https://doi.org/10.1016/j.jbusvent.2009.09.005

18. Dickey, M. H., McKnight, D. H., \& George, J. F. (2007). The role of trust in franchise organizations. International Journal of Organizational Analysis, 15(3), 251-282. https://doi. org/10.1108/19348830710880938

19. Doherty, A. M. (2009). Market and partner selection processes in international retail franchising. Journal of Business Research, 62(5), 528-534. https://doi.org/10.1016/j. jbusres.2008.06.011

20. Doherty, A. M., Chen, X., \& Alexander, N. (2014). The franchise relationship in China: Agency and institutional theory perspectives. European Journal of
Marketing, 48(9/10), 1664-1689. https://doi.org/10.1108/EJM-042012-0199

21. Dube, B., Mara, C., \& Ntimane, V. (2020). Perceptions of franchise stakeholders on trust in franchising relationships. African Journal of Hospitality, Tourism and Leisure, 9(1).

22. Fraser, J. R. S., \& Simkins, B. J. (2016). The challenges of and solutions for implementing enterprise risk management. Business Horizons, 59(6), 689-698. https://doi.org/10.1016/j.bushor.2016.06.007

23. Frazer, L., Weaven, S., Giddings, J., \& Grace, D. (2012). What went wrong? Franchisors and franchisees disclose the causes of conflict in franchising. Qualitative Market Research, 15(1), 87-103. https://doi. org/10.1108/13522751211192017

24. Gant, J. L. L., \& Buchan, J. (2019). Moral Hazard, Path Dependency and Failing Franchisors: Mitigating Franchisee Risk Through Participation. Federal Law Review, 47(2), 261-287. https://doi. org/10.1177/0067205X19831841

25. Grace, A. R., Frazer, L., Weaven, S., \& Dant, R. P. (2016). Building franchisee trust in their franchisor: insights from the franchise sector. Qualitative Market Research, 19(1), 65-83. https://doi.org/10.1108/QMR-092014-0085

26. Grace, D., \& Weaven, S. (2011). An Empirical Analysis of Franchisee Value-in-Use, Investment Risk and Relational Satisfaction. Journal of Retailing, 87(3), 366-380. https://doi. org/10.1016/j.jretai.2010.06.001

27. Grace, D., Weaven, S., Frazer, L., \& Giddings, J. (2013). Examining the Role of Franchisee Normative Expectations in Relationship Evaluation. Journal of Retailing, 89(2). https://doi.org/10.1016/j. jretai.2012.12.002

28. Harmon, T. R., \& Griffiths, M. A. (2008). Franchisee perceived relationship value. Journal of Business and Industrial Marketing,
23(4), 256-263. https://doi. org/10.1108/08858620810865834

29. Hodge, C., Oppewal, H., \& Terawatanavong, C. (2013). Determinants of franchise conversion: A franchisee perspective. European Journal of Marketing, 47(10), 1554-1575. https://doi.org/10.1108/EJM-102010-0540

30. Holmberg, S. R., \& Morgan, K. B. (2004). Retail marketing channel franchise failure: A strategic management perspective and longitudinal analysis. Journal of Marketing Channels, 11(23). https://doi.org/10.1300/ J049v11n02_04

31. Ishida, C., \& Brown, J. (2013). A taxonomy of monitoring in business-to-business relationships. Journal of Marketing Theory and Practice, 21(2), 123-140. https:// doi.org/10.2753/MTP10696679210201

32. Johnston, D. A., McCutcheon, D. M., Stuart, F. I., \& Kerwood, H. (2004). Effects of supplier trust on performance of cooperative supplier relationships. Journal of Operations Management, 22(1). https://doi.org/10.1016/j. jom.2003.12.001

33. Lee, Y. K., Kim, S. H., Seo, M. K., \& Hight, S. K. (2015) Market orientation and business performance: Evidence from franchising industry. International Journal of Hospitality Management, 44, 28-37. https://doi.org/10.1016/j. ijhm.2014.09.008

34. Liu, X. (2016). Corruption culture and corporate misconduct. Journal of Financial Economics, 122(2), 307-327. https://doi. org/10.1016/j.jineco.2016.06.005

35. Madanoglu, M., Castrogiovanni, G. J., \& Kizildag, M. (2019). Franchising and firm risk among restaurants. International Journal of Hospitality Management, 83, 236-246. https://doi.org/10.1016/j. ijhm.2018.10.021

36. Mainardes, E. W., Gomes, V. C. A., Marchiori, D., Correa, L. E., \& Guss, V. (2019). Consequences of customer experience quality on franchises and non-franchises 
models. International Journal of Retail and Distribution

Management, 47(3), 311-

330. https://doi.org/10.1108/

IJRDM-09-2018-0211

37. Nyadzayo, M. W., Matanda, M. J., \& Ewing, M. T. (2015). The impact of franchisor support, brand commitment, brand citizenship behavior, and franchisee experience on franchiseeperceived brand image. Journal of Business Research, 68(9), 18861894. https://doi.org/10.1016/j. jbusres.2014.12.008

38. Palmatier, R. W., Dant, R. P., Grewal, D., \& Evans, K. R. (2006). Factors influencing the effectiveness of relationship marketing: A meta-analysis. Journal of Marketing, 70(4). https://doi.org/10.1509/ jmkg.70.4.136

39. Perrigot, R., Basset, G., Briand, D., \& Cliquet, G. (2014). Network uniformity and risk of reclassification of the franchise contract. International Journal of Retail and Distribution Management, 42(10), 884901. https://doi.org/10.1108/ IJRDM-06-2013-0129

40. Raha, A., \& Hajdini, I. (2020). Franchisees with multiple stakeholder roles: perceptions and conflict in franchise networks. Journal of Strategic Marketing, 1-20. https://doi.org/10.1080/0965 254X.2020.1733052
41. Rodríguez, C. M., \& Wilson, D. T. (2002). Relationship bonding and trust as a foundation for commitment in U.S.-Mexican strategic alliances: A structural equation modeling approach. Journal of International Marketing, 10(4). https://doi.org/10.1509/ jimk.10.4.53.19553

42. Sanny, L., Abdurachman, E., Simatupang, B., \& Heriyati, P. (2017). Franchising Performance from Franchisee Perspective: Case in Education Franchising in Indonesia. Global Business Review, 18(3), 605-616. https://doi. org/10.1177/0972150917692168

43. Stanworth, J., Purdy, D., English, W., \& Willems, J. (2001). Unravelling the Evidence on Franchise System Survivability. Enterprise and Innovation Management Studies, 2(1), 49-64. https://doi. org/10.1080/14632440110056328

44. Wang, G., \& Lee, P. D. (2009). Psychological empowerment and job satisfaction: An analysis of interactive effects. Group \& Organization Management, 34(3), 271-296. https://doi. org/10.1177/1059601108330089

45. Watson, A., \& Johnson, R. (2010). Managing the franchisorfranchisee relationship: A relationship marketing perspective. Journal of Marketing Channels, 17(1), 51-68. https://doi. org/10.1080/10466690903436305
46. Weaven, S., Grace, D., \& Jones, R. (2012). Exploring brand extensions in the context of franchising in Australia. Journal of Brand Management, 19, 425437. https://doi.org/10.1057/ bm. 2011.50

47. White, D. W. (2010). The impact of marketing strategy creation style on the formation of a climate of trust in a retail franchise setting. European Journal of Marketing, 44(1/2), 162-179. https://doi. org/10.1108/03090561011008655

48. Winsor, R. D., Manolis, C., Kaufmann, P. J., \& Kashyap, V. (2012). Manifest Conflict and Conflict Aftermath in Franchise Systems: A 10-Year Examination. Journal of Small Business Management, 50(4). https://doi.org/10.1111/ j.1540-627X.2012.00369.x

49. Wright, O., \& Grace, A. (2011). Trust and commitment within franchise systems: an Australian and New Zealand perspective. Asia Pacific Journal of Marketing and Logistics, 23(4), 486-500. https://doi. org/10.1108/13555851111165048

50. Wu, C. W. (2015). Antecedents of franchise strategy and performance. Journal of Business Research, 68(7), 15811588. https://doi.org/10.1016/j. jbusres.2015.01.055 


\section{APPENDIX A}

Table A1. Risk management

\begin{tabular}{|c|c|c|c|}
\hline Indicator & Code & Statement & Reference \\
\hline Pre-investment screening & Pre & $\begin{array}{l}\text { The business reputation of a potential business } \\
\text { partner is important before starting a business } \\
\text { partnership }\end{array}$ & Grace et al., 2013 \\
\hline Due diligence & Due & $\begin{array}{l}\text { Before signing a franchise agreement, I must find } \\
\text { information about potential business partners } \\
\text { (via the internet, business colleagues, business } \\
\text { associations, etc.) }\end{array}$ & Blut et al., 2011 \\
\hline Market demand & Mrk & $\begin{array}{l}\text { Before starting a franchise there is no need to } \\
\text { conduct a market survey }\end{array}$ & Anderson and Weitz, 1992 \\
\hline Opportunistic behavior & Opp & $\begin{array}{l}\text { Opportunistic behavior (behavior that is not } \\
\text { in accordance with the franchise agreement) } \\
\text { sometimes appears in franchise agreements }\end{array}$ & Winsor et al., 2012 \\
\hline
\end{tabular}

Table A2. Franchisor-franchisee satisfaction

\begin{tabular}{|c|c|c|c|}
\hline Indicator & Code & Statement & Reference \\
\hline Resource access & Acc & No problems are accessing my colleague's resources & Palmatier, 2006 \\
\hline Communication openness & Com & $\begin{array}{l}\text { My business associates are available for open } \\
\text { communication }\end{array}$ & $\begin{array}{c}\text { Grace et al., 2013; Bordonaba-Juste } \\
\text { et al., } 2011\end{array}$ \\
\hline Perceived conflict & Con & $\begin{array}{c}\text { I am aware that conflicts can arise in franchise } \\
\text { agreements }\end{array}$ & Grace et al., 2013 \\
\hline Support & Sup & I get enough support from my business partners. & Palmatier, 2006; Grace et al., 2013 \\
\hline
\end{tabular}

Table A3. Survivability

\begin{tabular}{|c|c|c|c|}
\hline Indicator & Code & Statement & Reference \\
\hline Strategic achievement & S. AcV & $\begin{array}{c}\text { Periodically setting business targets and milestones } \\
\text { are not important }\end{array}$ & Stanworth et al., 2001 \\
\hline Business formula testing & BFtest & $\begin{array}{l}\text { The business formula test is important in a franchise } \\
\text { business }\end{array}$ & Stanworth et al, 2001 \\
\hline $\begin{array}{l}\text { Franchise expectations and } \\
\text { core competency fit or misfit }\end{array}$ & FECC & $\begin{array}{l}\text { The expectations and competencies of my business } \\
\text { associates are immaterial }\end{array}$ & $\begin{array}{c}\text { Holmberg and Morgan, 2004; } \\
\text { Davies et al., 2011; Winsor et al., } \\
2012\end{array}$ \\
\hline $\begin{array}{l}\text { Partners' complaint and legal } \\
\text { action }\end{array}$ & PrtcL & $\begin{array}{l}\text { If there are complaints and disputes, I will seek legal } \\
\text { advice }\end{array}$ & $\begin{array}{l}\text { Holmberg dan Morgan, 2004; } \\
\text { Boulay, 2010; Davies et al., 2011; } \\
\text { Winsor et al., } 2012\end{array}$ \\
\hline
\end{tabular}




\section{APPENDIX B}

Table B1. Questionnaire and scale

\begin{tabular}{|c|c|c|c|c|c|c|}
\hline No. & Question & Strongly disagree & Disagree & Neutral & Agree & Strongly agree \\
\hline 1 & $\begin{array}{l}\text { The business reputation of a potential } \\
\text { business partner is important for me before } \\
\text { starting a business partnership }\end{array}$ & & & & & \\
\hline 2 & $\begin{array}{l}\text { Before signing a franchise agreement, } \\
\text { I must find information about potential } \\
\text { business partners (via the internet, business } \\
\text { colleagues, business associations, etc.) }\end{array}$ & & & & & \\
\hline 3 & $\begin{array}{l}\text { Before starting a franchise there is no need to } \\
\text { conduct a market survey }\end{array}$ & & & & & \\
\hline 4 & $\begin{array}{l}\text { Opportunistic behavior (behavior that is not } \\
\text { in accordance with the franchise agreement) } \\
\text { sometimes appears in franchise agreements }\end{array}$ & & & & & \\
\hline 5 & $\begin{array}{l}\text { No problems are accessing my colleague's } \\
\text { resources }\end{array}$ & & & & & \\
\hline 6 & $\begin{array}{l}\text { My business associates are available for open } \\
\text { communication }\end{array}$ & & & & & \\
\hline 7 & $\begin{array}{l}\text { I am aware that conflicts can arise in franchise } \\
\text { agreements }\end{array}$ & & & & & \\
\hline 8 & $\begin{array}{l}\text { get enough support from my business } \\
\text { partners }\end{array}$ & & & & & \\
\hline 9 & $\begin{array}{l}\text { Periodically setting business targets and } \\
\text { milestones are not important }\end{array}$ & & & & & \\
\hline 10 & $\begin{array}{l}\text { The business formula test is important in a } \\
\text { franchise business }\end{array}$ & & & & & \\
\hline 11 & $\begin{array}{l}\text { The expectations and competencies of my } \\
\text { business associates are immaterial }\end{array}$ & & & & & \\
\hline 12 & $\begin{array}{l}\text { If there are complaints and disputes, I will } \\
\text { seek legal advice }\end{array}$ & & & & & \\
\hline
\end{tabular}

